\title{
PARAMETRIC STUDY ON THE INTERACTION FACTOR OF PILED RAFT
}

\author{
V.BALAKUMAR \\ Senior consultant, Simplex Infrastructures Limited, Chennai, Tamil Nadu, India, \\ vb_kumar2002@yahoo.com \\ MIN HUANG \\ Arup Geotechnics, Brisbane, Australia. \\ IVAN GARTCHEV, HANG YU QIN, MARK BOLTON \\ Lecturer of Civil Engineering GriffithUniversity Gold Coast Campus, Brisbane, \\ Australia \\ A.S.BALASUBRAMANIAM \\ Professor of Civil Engineering GriffithUniversity Gold Coast Campus, Brisbane, \\ Australia,bala.balasubramaniam@griffith.edu.au
}

\begin{abstract}
The performance of the piled raft foundation system depends upon the interaction level between the raft-soil-and the pile group. Understanding of this process is more complicates than the conventional pile group as the raft in contact with the ground influences the confining pressure, making the interaction behaviour more complicated. This paper presents a qualitative and a quantitative assessment of the interaction behaviour through a non dimensional interaction factor, through the results of a series of $1 \mathrm{~g}$ model studies. The effect of various important parameters like pile length, pile raft area ratio and spacing on the interaction factor are discussed.
\end{abstract}

\section{INTRODUCTION}

The design of foundation system to support structures that are either heavily loaded or sensitive for settlements was always tradition bound. Till recently deep piles had been the choice of the designers to support structures sensitive for settlement even when the bearing capacity of the ground was not a problem. Although the raft or the large pile caps were placed on favorable ground, the presence of the raft and its contribution in sharing the load is ignored and the design does not weigh the transfer of the load directly below the raft or the pile cap as the case may be. Many of the codes also recommend ignoring the contribution of the raft in the load transfer. Although this approach provides a safe design, the economics of the foundation design becomes questionable. However it is interesting to note that every structure has got certain amount of permissible settlement and this fact has come to recognition recently. This recognition has led to the advent of the combined piled raft foundation system as a viable alternative to deep piles when the ground conditions are favorable from bearing capacity point of view. The piled raft foundation system transfers the load by a three dimensional interaction among the constituent elements, namely the raft, pile and the soil. The interesting concept in the piled raft is that the pile group is intended to control the settlements; in the initial stages of serviceability, the pile group provides most of the stiffness, and the raft elements provide the additional capacity at ultimate loading. 
Extensive research has been done so far on the behaviour of piled raft and various aspects of behaviour relating to the load settlement and the load sharing response have been studied in detail by various researchers like Reul [1],Poulos[2] and so on. Based on such works the piled raft foundation has been used to support structures not only on favorable ground conditions as shown by Poulos[3] but also on unfavorable ground conditions with ground improvement techniques as reported by Yamashita etal.,[4].However it appears that the phenomenon of the interaction between the constituent elements have not been studied in detail. As pointed out by Lee and Chung [5], the complex interaction can become favorable like increase in the group capacity or unfavorable like causing additional settlement. The study on the interaction behaviour gains importance as in the case of piled raft the interaction takes place between the pile - raft -and the soil.

\section{THE STUDY}

The study was carried out by conducting a series of $1 \mathrm{~g}$ model tests on circular, square and rectangular shaped piled raft. The tests included tests on un-piled raft, free standing pile group and the piled raft. The tests were carried out in steel tank by preparing the bed adopting sand raining process in pre-calibrated manner so that the required densities could be achieved. Although extensive parametric studies were carried out this presentation is restricted to circular piled raft on medium dense sand. The $8 \mathrm{~mm}$ thick raft diameter was kept as $200 \mathrm{~mm}$; the piles were $10 \mathrm{~mm}$ dia $160 \mathrm{~mm}$ long and the pile -raft area ratio was kept as $5.2 \%$ and the 21 piles were placed in radial grid pattern. Loading was applied in small increments till the settlement reached $20 \mathrm{~mm}$ namely 10 $\%$ of the raft diameter. The bed material was poorly graded palar sand.

\section{RESULTS ANALYSES AND DISCUSSIONS}

Figure 1 presents the load settlement response of free standing pile group and pile group of piled raft. In the case of free standing pile group the raft was not in contact with the soil and was kept $40 \mathrm{~mm}$ above the bed level. Load was applied in small increments till the settlement reached $20 \mathrm{~mm}$.

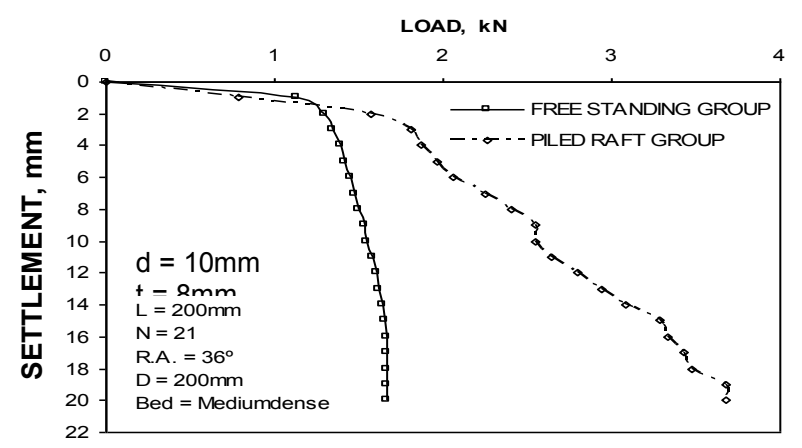

Figure 1. Comparison of load-settlement response of free standing pile group and pile group of piled raft

The response of pile group of piled raft was obtained from the load settlement response of un-piled raft and pile raft; the load taken by the un-piled raft was deducted from the load taken by the piled raft at each settlement level to get the load taken by the pile group of piled raft. It is seen from the 
figure that in the initial stages till the settlement reached $1.2 \mathrm{~mm}$, the free standing pile group was exhibiting a very high stiffness. The load corresponding to this settlement level was $1.2 \mathrm{kN}$ which is almost $75 \%$ of the load taken by the free standing pile group corresponding to $20 \mathrm{~mm}$ settlement. Beyond this level, even for a small increment in the load, the pile group of piled raft settled rapidly, which means that once the friction is overcome the pile group of piled raft failed instantaneously. The free standing pile group took only $25 \%$ of load further. In the case of pile group of piled raft till the settlement level reached $2 \mathrm{~mm}$, the response was very stiff and the load at this level was $1.8 \mathrm{kN}$ which is nearly $50 \%$ more than the load taken by the free standing pile group. Thereafter as the as the load increase, the stiffness of the pile group of piled raft was falling down rapidly although it was taking further load.

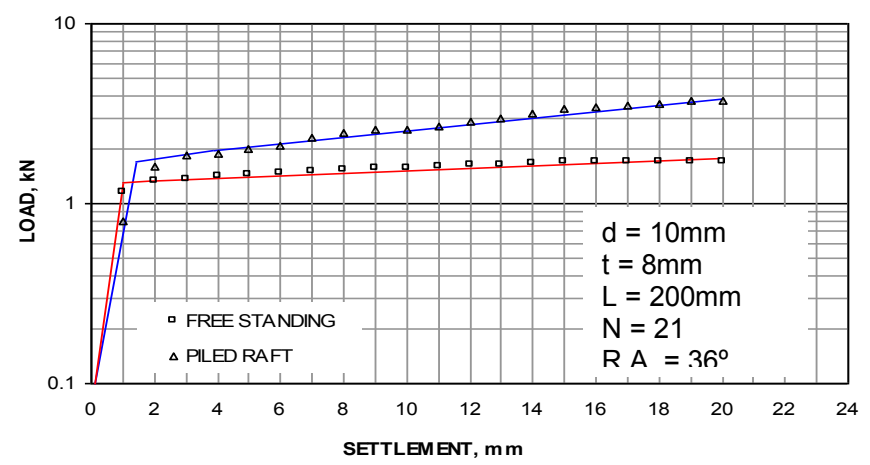

Figure 2. Characteristic response of freestanding pile group and pile group of piled raft

The characterized load settlement response presented in Figure 2 clearly shows that the freestanding pile group has a two phase response with the initial stage showing a stiff response till the friction is overcome. Once the friction is overcome the pile group loses its stiffness instantaneously. In the case of pile group of piled raft although the response is similar to that of freestanding pile group, till major part of the friction is overcome. Even though the pile group of piled raft started losing its stiffness rapidly it continued to take further load which is similar to elastic work hardening behaviour.

\section{QUALITATIVE ASSESSMENT}

The interaction between the raft pile and the soil can be explained based on the interesting hypothesis proposed by Chin [6].The mobilization of stress in a soil with increase in the strain is a function of an increasing number of effective soil contacts rather than of a general increase in the intergranular stress on a constant number of grain contacts. It may be visualized that when the soil mass is under a compressive stress the load is transmitted by internal columnar grain structures and that as they reach the limiting loads more and more columns begin to support the load each having approximately same yield load. It is seen that as the pressure applied from the raft increases, the assembly of columnar structure become denser creating higher confining pressure. Once the applied stress increases beyond the limiting value, the grain structure tends to collapse or does not resist the applied stress but pile soil system stiffness remains at the enhanced value, helping the raft to take higher load. It is seen that in the initial stages the stiffness is very high. The loss of stiffness is gradual till the settlement reaches $6 \mathrm{~mm}$ and at the final settlement of $20 \mathrm{~mm}$ the 
stiffness is very low but the system takes a higher load due the stiffness gained by the grain columns.

\section{QUANTITATIVE ASSESSMENT}

Although the interaction behaviour has been qualitatively established, quantification has to be done through a suitable parameter in non-dimensional form mainly because the interaction is a measure of varying relative stiffness. Randolph [7,8] in his studies had expressed the interaction between the pile and the cap considering the average displacements beneath the cap due to the loading on the pile, and down the center line of the pile due to the cap. Clancy [9] had later established the raft pile interaction factor apr and based on this, more rigorous analyses were conducted to show that the value is constant as the number of piles increases. The value suggested was around 0.8 . The interaction factor is expressed as

$$
\mathrm{K}_{\mathrm{pr}}=\mathrm{K}_{\mathrm{p}}+\frac{\left(1-2 \alpha_{\mathrm{pr}}\right) \mathrm{K}_{\mathrm{r}}}{1-\alpha_{\mathrm{pr}}^{2}\left(\mathrm{~K}_{\mathrm{r}} / \mathrm{K}_{\mathrm{p}}\right)}
$$

Where, $\mathrm{Kpr}$ is the stiffness of the piled raft, $\mathrm{Kp}$ is the stiffness of the pile group, and $\mathrm{Kr}$ is the stiffness of the raft. All measured at the same settlement level. $\alpha$ pr is the interaction factor.

Based on the parametric studies conducted through the $1 \mathrm{~g}$ model tests the stiffness of the individual elements namely the raft $(\mathrm{kr})$ and the pile group as pier (kp) and the piled raft (kpr) were computed at different settlement levels using Excel programme and the value of apr was computed for various pile lengths, pile-raft area ratio in the case of circular piled raft and pile spacing in the case of circular piled raft. It is to be noted here that the number of piles were varied keeping the raft dimension constant.

\section{Effect of pile length}

Figure 3 a presents the bilinear variation of the interaction factor with the pile length at different settlement level. At a settlement level of $2 \mathrm{~mm}$ the interaction factor is unity mainly because the pile group shares the maximum load due to the high intergranular stress created. As the settlement level increases the interaction factor reduces and at $20 \mathrm{~mm}$ the value is the least.

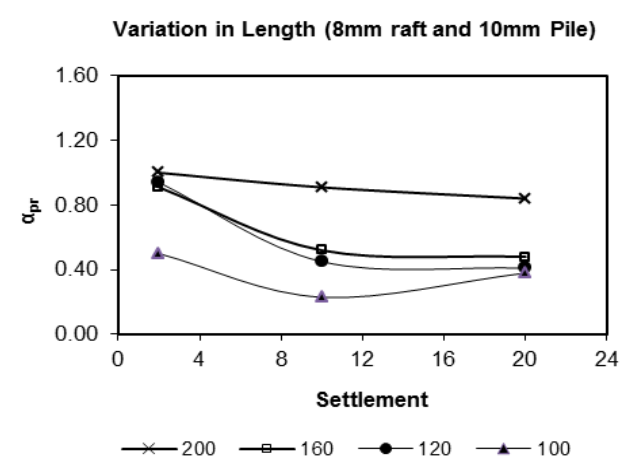

a

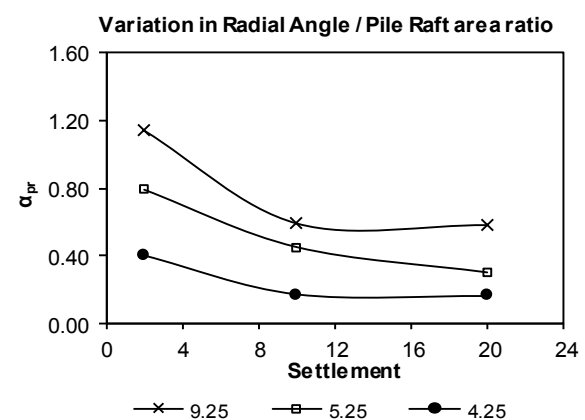

$\mathrm{b}$

Figure 3. Effect of pile length and pile raft area ratio on $\boldsymbol{\alpha}_{\mathrm{pr}}$ 
It is seen that when the pile length is 0.8 times the raft diameter the interaction factor varies from 0.5 to 0.9 . As the length reduces the interaction factor range comes down. However it is seen that the interaction factors around 0.8 when the length is 0.8 times the raft width at a settlement level of $10 \mathrm{~mm}$ of the pile group of piled raft changes its slope marginally stiffness falls rapidly; at this settlement level pile group has developed the total friction.

\section{Effect of pile - raft area ratio}

The variation of the interaction factor with pile raft area ratio is given in Figure $3 b$. The variation shows identical trend.

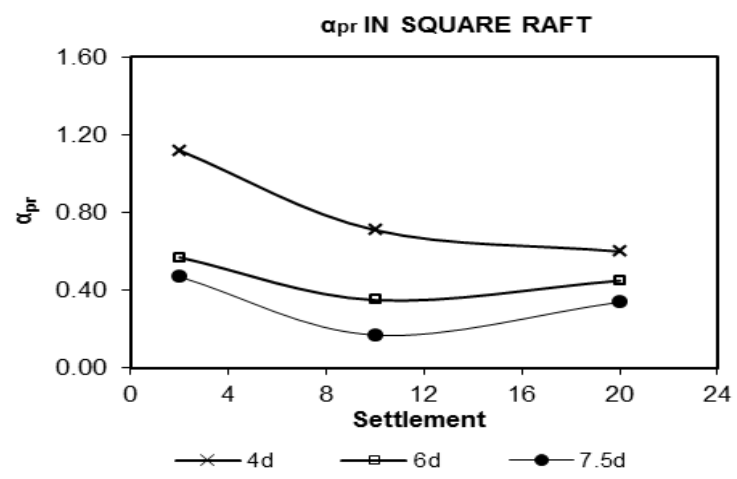

Figure 4. Effect of pile spacing on $\alpha_{\mathrm{pr}}$

When the pile raft area ratio is very high $(9.25 \%$ with 37 piles) the interaction factor varies from 0.8 to 1.2 indicating that the piled raft has a tendency to behave as a fully piled system. When the area ratio is $5.25 \%$ ( 21 piles) the variation is from 0.4 to 0.8 . When the area ratio is small the interaction factor is also small. It is seen that at a settlement level of $10 \mathrm{~mm}$ when the load settlement response takes elasto plastic stage the interaction factor varies from 0.6 to 0.8 depending on the concentration of piles.

\section{Effect of pile spacing-Square piled raft}

It is seen that when the spacing is $4 \mathrm{~d}$ the concentration of piles are more ( 25 piles) resulting in a higher level of interaction as seen from the variation of interaction factor. The interaction factor varies from 0.75 to 1.2 ; at $2 \mathrm{~mm}$ settlement the pile group has very high stiffness and tends to function as fully piled. At a spacing of $7.5 \mathrm{~d}$ the interaction level is very low. But at a spacing of $6 \mathrm{~d}$ the interaction level appears to be optimum with a variation of interaction factor between 0.45 to 0.75.This indicates that a spacing of $4 \mathrm{~d}$ to $6 \mathrm{~d}$ will be the most optimum spacing for an optimum performance of the piled raft.. From the above study it is seen that when the number of piles length and the spacing is higher the interaction factor is close to unity at the initial settlement level of $2 \mathrm{~mm}$ and on the other hand when they are low the interaction factor is around 0.4 to 0.6.This behaviour indicates that when the load level is such that the entire friction is mobilized the interaction factor reduces but the system takes higher load compared to that of un- piled raft. However at a settlement level where the load settlement response reaches elasto - plastic level irrespective of the shape of the piled raft the interaction factor varies from 0.6 to 0.8 which is .close to the value predicted by Randolph [7] namely 0.8 . The overall variation of the interaction factor under identical condition of EP/ES as 100 predicted by Randolph [7] is 0.59 to 0.75 and 
based on the $1 \mathrm{~g}$ model tests is 0.5 to 1.0 .Although the variation appears to have a wider spectrum it is to be noted that the study by Randolph [7] is based on numerical modelling and the present study is based on ig model with bed material as sand. However under certain optimum conditions the variation is similar to what has been obtained by Randolph [7].

\section{CONCLUSIONS}

The interaction behaviour of piled raft was studied through a series of $1 \mathrm{~g}$ model tests and the nondimensional interaction factor which is a function of the pile group, raft and the piled raft stiffness was evaluated under various parametric conditions. It was established that the columnar grains contribute to the enhancement of the confining stress leading to the higher pile group stiffness and to the increased capacity of the whole system The interaction factor was computed from the model tests and were compared with the values predicted by Randolph. The variation was found to be somewhat wider but perhaps within an acceptable level as the method of study was different. However broadly the value varies from 0.6 to 0.8 at the elasto plastic stage corresponding to a settlement level of $8 \mathrm{~mm}$ to $10 \mathrm{~mm}$ in the model tests, which is in close agreement with predicted value with numerical analyses by Randolph.

\section{REFERENCES}

[1] Reul O. (2000), 'In-Situ Messungen Und Numerische Studien Zum Tragverhalten Der Kombinierten Pfahl-Plattngrundung', Mitteillungen Desinstituts Und Der Versuchanstilt Fur Geotechnique Der Technischen Universitadt. Darmstadt. Heft.53.

[2] Poulos H.G. (2001), 'Piled Raft Foundation: Design and App.lication', Geotechnique, Vol. 51, No. 2, pp. 111-113.

[3] Polous H.G. (2008), "The Piled Raft Foundation for the Burj Dubai - Design \& Performance”. IGS - Ferroco Terzaghi, Oration - 2008.

[4] Yamashita K, Hamada J, Yamada T. (2010), Field Measurements On Piled Rafts with GridForm Deep Mixing Walls on Soft Ground, Geaotechnical Engineering-SEAGS Vol.42 No 2 June 2011

[5] SU - Hyung Lee and Choong - Ki Chung . (2005) An Experimental Study of the Interaction Of Vertically Loaded Pile Groups In Sand-Can.Geoteh. Journal 42 -pp1485-1493

[6] Chin F.K. (1972), 'The Inverse Slope as a Prediction of Ultimate Capacity of Piles', Proc. $3^{\text {rd }}$ S. E. Asian Conf. on Soil Engg, Hongkong, pp. 83-91.

[7] Randolph M.F. (1983), 'Design of Piled raft Foundation', Proceedings of Recent Developments in Laboratory and Filed Tests and Analysis of Geotechnical Problems, Bangkok, pp. 525-537.

[8] Randolph M.F. (1994), 'Design Methods for Pile Group and Piled Rafts', Proc. 13 ${ }^{\text {th }}$ International Conference on Soil Mechanics and Foundation Engineering, New Delhi, pp. 5,61-82.

[9] Clancy P. (1993), Numerical Analysis of Piled Raft Foundations, University of Western Australia, PhD Thesis. 